\title{
Legal Status of religious place and Legalization Trend in China
}

\author{
YanLi \\ School of Humanities, China University of Political Science and Law, Beijing 100088, China \\ tyylty@163.com
}

Keywords: Religious activity Places, Religious groups, Legalization, Government.

\begin{abstract}
At present, the place of religious activities in China does not have independent legal status, and must have four legal elements to become a legitimate social organization. The development of democracy and rule of law in China has promoted the demand of religious activities, and requires legal personality as an independent social organization in order to self-determine its organization affairs according to the laws.
\end{abstract}

\section{Introduction}

A religious place is a location where religious ceremonies and religious activities are held. It is also a location for clergy and general believers to communicate, as well as the main economic source of life for the clergy. The religious place is a space with a spiritual function and interest function. Since the restoration of religious activities in China in the early 1980s, the economic, cultural and tourism values have been of concern. Moreover, the phenomenon of religious zeal and religious chaos coexist in China. In recent years, monk heritage cases, conflictions between monks and tourists , and even conflictions among the monastery and the surrounding areas and the surrounding community, rural illegal small temple, illegal home church and other issues that continued to emerge, and led to legal attention and discussion about the place of religious activities.Until mid-2012, the opening of the legitimate religious activities that China has approved were nearly 130,000 places, among of which are about 33,000 Buddhist temples, about 50,000 Taoist temples, about 39,000 Islamic mosques, about 0.5 million Catholic churches, and about 44,000 Christian churches and family meeting points.[1] There are still a large number of the places of religious activities which have not been legitimated due to the lack of the registration.

\section{The legal elements of the places of the religious activities}

According to the current Regulations on Religious Affairs in China, religious venues include monasteries, palaces, mosques, churches and other fixed religious activities. "Other fixed religious activities" mainly refers to the locations other than temple, mosques and churches, where the religious believers often hold some collective religious activities, such as Christian gathering point. Compared with the formal religious places, the fixed space is generally smaller, and has fewer religious believers, without religious faculty, religious building and religious regulations. It could be only in simple houses.

As of now, the religious places in China include the old religious places that have resumed their religious activities after examination and approval, and the new religious places that are built by religious organization. A legal religious place is a non-profit social organization that is legally established to carry out religious activities in accordance with religious purposes and religious doctrines. It must have the following four elements:

\subsection{The main elements}

The main body of a religious place can be either an individual or a collective. Individuals can live in accordance with religious habits, in the right places such as home, to pray, chant, worship, fast and leadother religious life. Individual religious life is bound by law. Collective religious activities should be held at religious venues registered in the government's religious affairs department, namely, Buddhist monasteries, Taoist temples, Islamic mosques, Catholic and Christian churches, 
and other legally registered places for religious activities. There is no clear legal requirement for individual and collective standards. Family religious gatherings have relative legitimacy. Some provinces in China regulate family religion party to be less than 10 persons. Once the gathering is beyond the scope of family members and a large amount of people involved, it becomes the private meeting of the religious point and needs to be registered. Otherwise, it would be banned by the government in accordance with illegal religious place.

\subsection{The spatial elements}

Religious space is a special holy place used for religious purposes. The religious places are physically reflected as houses, lands and other fixed locations where the religious citizens would meet for the needs of religious activities. Religious activities must be held in religious places. The scope of religious activities is the area of action for religious activities. If collective religious life has be to performed outside the registered place of religious activities, such as holding large religious activities or religious citizens to invite religious faculty members to their home or other places such as funeral parlors, cemeteries, etc. in order to held religious ceremonies, it should be applied in accordance with the law. In recent years, with the development of the Internet, there have been also new challenges for identification and management of the place of religious activities in China.

\subsection{The behavior elements}

Religious activitiesare the expression of "the religious experience and religious beliefs of religious believers through external physical movements and language forms".[2] Religious activities include broadly religious activities carried out by religious believers. The narrow sense refers only to religious activities carried out collectively by religious people.[3] Religious activities can be divided as the dominant and ancillary activities. The dominant activities include the ones that the believers perform in accordance with the religious doctrine, such as chanting, incense, worship, pray, preaching, mass, baptism, ordination, fasting, memorial and other religious holidays. The other religious activities, such as the establishment of public welfare undertakings, carrying out foreign exchanges, tourism, and distribution of religious supplies are ancillary activities. The ancillary activities can not affect the main religious activities of religious citizens. Religious activities can also be defined as legitimate orillegitimate. Religious activities in accordance with the law in the legal place are legal religious activities; otherwise are illegal religious activities.

\subsection{The legal element}

Religious activities as a legal subject, must meet the conditions and the implementation of the procedures definedby law. According to Articles of the Regulations on Religious Affairs(2017), the establishment of a place of religious activities shall meet the following conditions: (a) the purpose of establishment does not violate the provisions of Articles of the Regulations; (b) the need for collective religious activities; (c) the religious faculty who are to preside over religious activities or other persons who meet the requirements of this religion; (d) have the necessary funds; (e) reasonable layout, without prejudice to the normal surroundings and residents production and life. "The newly revised" Religious Affairs Ordinance "(2017) has increased the legal requirements for funding sources. According to the provisions of the Religious Affairs Ordinance, the establishment of religious activities venues into the preparatory stage of approval and the stage of registration.

Those places where religious activities are not in complywith the above four elements of establishment are privately established places of illegal religious activities, which are banned by the state.

\section{It is the inevitable trend of religious autonomy to allow religious places to obtain the legal personality.}

According to the newly revised Religious Affairs Ordinance (2017), the religious place in China may have an independent legal personality and belong to an organization in civil law. According to 
the conditions of legal personality of the civil law, religious places could register as legal person at the same time for legal registration. The legalization of religious places as a long-term legal system will help to solve the existing problems, such as legal positioning, property management and rights maintenance in religious places, and help to uniform the different understanding of religious places between government departments. However, the most religious places do not have civil legal personality, leading to many obstacles when they exercise civil capacity. These religious places without legal personality depend on communications and other measurements to resolve these kinds of problems through government and religious organizations.

The legal personality of a religious place means transformation of a religious place from a traditional place organization to a modern organization. This change is the demand for religious autonomy. Religious organization autonomy including: (a)organizational autonomy, that is, the form of religious organization has the right to choose the form of association that is a community-based corporation or a place-like legal person, and can change the organization form in the course of existence; (b) personnel autonomy, that is, religious organizations have the rights of appointments, promotion and removal of internal organizations; (c)financial autonomy;(d) regulatory autonomy, that is, religious organizations that have right to regulate the rules and regulations for their members. Once a religious place obtains legal personality, itmeans that the religious site become a legal person, so that it can determine its organizational affairs according to their own doctrine within the scope of the law, such as personnel, education, capital and place of business activities, and the state respects and protect the autonomy right of religious organizations in accordance with the Constitution.

The legalization of religious places is necessary for religion to meet the needs of modern society. Religious places have adapted to the Chinese traditional closed self-sufficient small-scale peasant economic form. However, religious association that be organized adapt the open form of commodity economy model. In Chinese history, religious association that has used the model "place" rather than socialized organization has its economic, political, cultural and other reasons. China's current legislations regard religious places as an organization rather than a place. But the place of religious activities from the concept to the practice embodies a religious belief in the space of the "presence of unity". Space is the center of the religious identity and religious cohesion. Religious space shows static and permanent characters. But the religious organization stressed that members of the "absence of unity" and the center of the organization is the unanimous endorsement of the members, so it presents the characters such as dynamic and fast. In the traditional Chinese community-style, religious association culture is closely linked with the symbols of the old times such as farming culture, authoritarianism, clan construction and so on. The focus point about religious places transfers from the location of religious places into the action of organization, and this change underlines the rules, structure of the organization. Finally, this change will make religious places become a modern organization from the inside to the outside. This change has the driving force within the religious places, that is, the religious places strive to the objectives such as the initiative, integrity and independence of the right and responsibility of legal action. It also has an external driving force, that is, the change is the result of the development of economic strength, social structure, ethics, democracy and the rule of law.

\section{The current problems of religious places in China}

\subsection{The relationship between religious places and religious groups}

Religious groups enjoy exclusive authority with quasi-government management functions. Religious activities places have a legal design dependency on religious groups. Religious activities of religious places must be approved by religious groups, such as organization pilgrimage, administration religious internal affair, religious publishing and faculty identified. And religious groups are mostly funded from the government's appropriation and religious donations. As a result, the economic independence of religious group is weak. Most religious groups do not have independent office space, relying on local religious places. Religious places and religious 
organizations coexist with each other, and mutual depend and restraint. The relation of both is convenient to be managed and controlled by the government. If the religious places have a complete legal personality and independence, the phenomenon of the "weak group, strong place" would continue to be strengthened in the religious economic benefits. Therefore, how to solve the problem between religious places and religious groups will be a hot topic in the future religious studies.

\subsection{The inside corruption problems of the religious place}

Many Buddhist and Taoist religious sites have not yet established a sound internal management organization. The property of these religious sites is mainly managed by the person in charge of the place of religion. Sometimes the property of these religious sites entrusts the believer or the third person to manage. The property management system is a kind of agent system between the organization and the internal members, and easily leads to civil disputes about property, infringement and criminal litigations about inheritance and occupation, misappropriation of collective property. This property management system also increases the moral burden of property managers.

\subsection{The excessive reliance on the government in the course of the existence of religious sites}

At present, most of the religious places do not have independent legal personality status, so they require the Government to help solve the kinds of problems that encountered in the course of their existence. The government's religious affairs department communicates with other government departments to solve the problems of the religious places. For example, the government's religious affairs department consult the problems of tickets with the National Development and Reform Commission, the problems of the real estate with real estate management departments, the duty-free accreditation and the Ministry of Human Resources and Social Security consultative staff social security issues, and so on. The participation of the government in consultation helps religious places to solve the various problems in the process of religious development. This will increase the dependence of religious places on the government, so that the government is easier to implement the coercion strategies on religious places.

\section{Summary}

To properly solve the problem of the legal status of religious places is actually a matter of religious autonomy. There is no full autonomy in Chinese religion. Even if the law gives autonomy to religious organizations, it is still reduced in practice. Moreover, the starting point of legalization of religion and religious organizations is to control and limit. It is worth discussing the question that whether the legal status of the religious place can solve the most problems in the existence process of the religious places, such as commercialization and capitalization of religion.

\section{References}

[1] Wang Zuoan. Grasp the law, pioneering and innovative, do a good job of the management of religious activity places under the new situation [J]. Chinese Religion.2012 (6): 4-9.

[2] Lu Daji. Religious theory of the new series (volume 1) [M]. Beijing: China Social Science Press.2004: 293.

[3] Shuai Feng, Li Jian. Interpretation of the ordinance of religious affairs [M]. Beijing: Religious Culture Press .2005: 19. 